\title{
Comparison of the Effectiveness of Audit Committees in the UK and Turkish Banks
}

\author{
Nizamülmülk Güneş ${ }^{1} \&$ M. Serkan Atılgan ${ }^{1}$ \\ ${ }^{1}$ Department of Audit, Savings Deposit Insurance Fund, Istanbul, Turkey \\ Correspondence: Nizamülmülk Güneş, Tasarruf Mevduati Sigorta Fonu (TMSF), Denetim Dairesi, Buyukdere Cd. \\ No:143, Esentepe, Istanbul, 34394, Turkey. \\ Received: January 6, 2016 \\ Accepted: January 25, 2016 \\ Online Published: February 17, 2016 \\ doi:10.5430/ijfr.v7n2p18 \\ URL: http://dx.doi.org/10.5430/ijfr.v7n2p18
}

\begin{abstract}
The audit committee effectiveness (ACE) has been researched for several times by academics in accounting and finance literature in terms of relationships with earnings management, corporate governance mechanism, power types and, audit fee etc. This study aims to measure of the emphasize of effective audit committees (ACs) on bank performance via using some of the main bank performance indicators which are return on asset (ROA), return on equity (ROE) and net interest margin (NIM) in the Turkish and the UK banks during 2006-2010.
\end{abstract}

Keywords: audit committee, audit committee effectiveness, banking industry, return on assets, return on equity

\section{Introduction}

In this study we aim to associate the characteristics of ACE (number of members in audit committee (AC), number of independent members in AC, number of AC meetings, financial expertise of members in AC, education level of members in AC, age, gender diversity and experience of members in $\mathrm{AC}$ with bank performance in the means of bank measure ratios (ROA, ROE and NIM) in the Turkish and UK banks during 2006-2010.

With high-profile financial fraud cases in early of this decade, academic and industry search for effective AC's to provide sound monitoring (Chan and $\mathrm{Li}, 2008$ ). ACE is very important for sound Corporate Governance practices in the organization (Campbell, 1990) and lack of effective Audit practice is a reason behind rigorous financial problems of companies (Vicknair et al., 1993).

Turkey has relatively a short history on corporate governance especially concerning the concept of AC practices. The background of the ACs in Turkey dates back to the year 2003. On the other hand, UK has a relatively long experience on AC practices and it starts from Cadbury Report in 1992. Logically it should give UK a reasonable chance to stand to financial crises. However, the financial crises that emerged in the late 2000s in UK have affected deeply UK banking sector more than Turkey's banking sector.

This notion encouraged us to work on the AC to analyze the state of ACs in the UK and Turkish banking sector whether they are used as strong corporate governance tools to oversight the financial reporting process. In order to perform that we investigate the effectiveness of ACs and their contribution level to the bank functioning in the means of bank performance measures. However, very limited research has been to evaluate ACE in UK and Turkey in a comparative way, this study can provide a framework for further research into the effectiveness of ACs between these countries.

The data analyses involved the use of descriptive statistics. Due to the data set have both time series (2006-2010) and dependent and independent variables, Panel data analysis is used in this study.

\section{Audit Committee (AC)}

The AC is defined as the existence of a subcommittee of the main board comprised mostly of non-executive or independent directors with responsibility for oversight of auditing activities (Collier, 1993). The UK Combined Code recommends that: "The board should establish an AC of at least three, or in the case of smaller companies two, independent non-executive directors. In smaller companies the company chairman may be a member of, but not chair, the committee in addition to the independent non-executive directors, provided he or she was considered independent on appointment as chairman. The board should satisfy itself that at least one member of the AC has recent and relevant financial experience" (FRC, 2012). 
In Turkey, Banking Law No 5411 notes that AC shall consist of minimum two members and The Communiqué Regarding The Independent Auditing Standards In The Capital Markets - Serial X Number 22 denoted that listed companies have to establish an AC that have at least two members who shall be selected by and among the board of directors. If committee has two members, both of them, if committee has more than two member, majority of them cannot be from a executive post like general manager or executive committee member in the board of directors. AC members shall be appointed amongst the members of the board of directors who do not have executive duties (Banking Law No 5411, 2005).

Rickard (1993) describes the AC as “... consists of a group of senior staff, chaired by the chief executive officer or his deputy. The committee's responsibility is to safeguard the independence of the internal audit function and ensure continual improvement in management performance and accountability by seeking action on internal audit and external audit reports."

Another definition sees the AC in terms of its expected responsibilities and functions; "The AC is a committee composed of independent, non-executive directors charged with oversight functions of ensuring responsible Corporate Governance, a reliable financial reporting process, an effective internal control structure, a credible audit function, an informed whistleblower complaint process and an appropriate code of business ethics with the purpose of creating long-term shareholder value while protecting the interests of other stakeholders" (Rezaee, 2009).

The main reasoning of the establishment of the $\mathrm{AC}$ is to answer the constantly changing business environment and to assist the board of directors and management to deal with those challenges said Bromark and Hoffman (1992) in their study. They also added up following challenges as:

- "Widening concern regarding corporate ethics.

- A cry for fair disclosure of the quality of the company's earnings and financial condition, and the resulting responsibility of management and the board for full and fair disclosure of financial results.

- Globalization of markets, which has opened new opportunities, increased competition, and created an explosion of the information required to make informed decisions.

- Widespread use of information technology, including microcomputers and networks, satellite transmissions, and introduction of electronic data interchange, all of which have changed internal control methods."

\subsection{The Development of Audit Committees in UK and Turkey}

A historical review of the development of audit committees in the UK and Turkey will highlight the significance of such committees to ensure high quality, trustworthy financial reporting and hence by implication the need for an effective audit committee to develop the reliability of companies' financial reports.

\subsubsection{Audit Committees in UK}

Audit committees has gained impetus start from Cadbury Report mainly as a result of corporation failures due to poor corporate controls and low confidence in the credibility of financial statements, and the independence and effectiveness of the external audit function in UK. In view of these problems, more attention was given to the establishment of audit committees and their role to enhance the reliability and quality of financial statements.

In 1977, the Companies Bill tried to advocate for legislation on the establishment of audit committees however, its efforts were unsuccessful (Dafinone, 2001).

In 1986, an Institute of Chartered Accountants of England and Wales working party recommended that audit committees be responsible for both the appointment and remuneration of auditors, the approval of audit plans and the review of management reports issued by auditors. In 1987, the Bank of England issued a paper entitled "the Role of Audit Committees in Banks" that recommended that all banks have to establish an audit committee (Vanasco, 1994). In the same year, the London Stock Exchange also recommended that all listed companies should establish audit committees composed of non-executive directors.

The Financial Reporting Council, the Accountancy Profession and the London Stock Exchange set up the Committee on the Financial Aspects of Corporate Governance to talk to the financial characteristics of corporate governance in 1991 (NFCG, 2011). In 1992, The Cadbury Report was published by the committee (ICAEW, 2012). This report required that all companies listed on the Stock Exchange should disclose, as a continuing listing obligation, a statement of compliance with the Code of Best Practice.

The Higgs Committee Report was published in January 2003 and focused on the role and importance of non-executive directors on the board. Specifically, the board is to operate through a number of sub-committees including the remuneration, the nomination and the Audit Committees. These committees are to comprise mainly of non-executive directors who are independent of the management. 
In 2002, the government requested the Financial Reporting Council (FRC) to review the country's preparedness in preventing such a collapse in UK listed companies. A report by FRC-Appointed Group was submitted to the FRC in December 2002 and published in January 2003. This report is well known as the Smith Guidance on Audit Committees. The committee proposed new code provisions on the Audit Committee that should be included in the Combined Code. This guidance is planned to help directors serving on the board of audit committees in performing their role and support companies in making appropriate actions for their audit committees.

In July 2003, the FRC issued its latest report regarding Corporate Governance entitled the Combined Code on Corporate Governance. The Combined Code issued by the Hampel Committee (1998) on Corporate Governance is taken the place of and replaced by this Combined Code. It derives from a review of the role and effectiveness of non-executive directors (Higgs, 2003) and a reassessment of audit committees. The new Code is planned to apply for reporting years beginning on or after 1 November 2003. Since its first version, the Combined Code has been updated on a regular basis in line with developments in the corporate environment and changes in the global Corporate Governance guidelines that are deemed necessary in the context of the UK.

Despite the fact that the establishment of audit committees is not mandated by statute in the UK, the self-regulation approach, which has been taken by government through the FRC, requires all listed companies to disclose in their annual reports the degree of compliance with the Combined Code on Corporate Governance. It is felt that a statutory regime would not be as flexible and adaptable as a self- regulatory system (Financial Reporting Council, 2003).

\subsubsection{Audit Committees in Turkey}

The background of the audit committees in Turkey dated back to the year 2003 in which the Capital Markets Board had issued the Corporate Governance Principles. That work was followed by the Banking Law No. 5411 of the Banks Association of Turkey, the Communiqué regarding the independent auditing standards in the Capital Markets released by the Capital Markets Board, the Board Decision on qualifications of the audit committee members and the Guideline about the authorization and the activities of the independent audit firms that will perform auditing in banks respectively.

Capital Markets Board of Turkey (CMB) Corporate Governance Principles consisted of four main parts which are:

1-Shareholders

2-Public Disclosure and Transparency

3- Stakeholders

4- Board of Directors

Under the last part of the Principles, there is a section named Number, Structure and Independence of Committees Established by the Board of Directors. Here the duties of the audit committee were specified. As we can cite from the Principles:

"An audit committee in charge of supervision of the financial and operational activities of the committee should be established.

- The board of directors shall provide all necessary sources and assistance to the audit committee for its duties to be performed. The committee should be entitled to invite any executive, internal and external auditors to the committee meetings and to obtain their opinions.

- The audit committee should supervise whether or not periodic financial statements including footnotes are prepared in accordance with the current legislation and international accounting standards and should declare its opinion to the board of directors in writing upon receiving the opinion of the independent audit firm.

- The audit committee should take all necessary measures in order to ensure that internal and external auditing are carried out adequately and transparently.

- Appointment of the external audit company and the services to be provided thereby should only be submitted to the board upon the preliminary approval by the audit committee. Prior to appointment of the external audit company, the audit committee should prepare a report stating whether or not there exist any issues that may jeopardize independence of the audit company.

- The audit committee should evaluate and resolve any issues pertaining to the complaints and suggestions on the accounting practices, internal control system and external auditing as submitted to the company and also ensure that complaints made by the employees in this respect are evaluated in accordance with confidentiality principle. 
- The audit committee is entitled to obtain opinions of the independent experts as it deems necessary regarding its operations. The respective fees for consulting services as required by the audit committee should be reimbursed by the company.

- The audit committee should convene at least once in three months and submit the outcome of such meeting to the board of directors. The external audit company should participate in the meetings regarding the evaluation of the financial statements and should provide information about its work. (CMB, 2003)

The Banking Law No. 5411 was amended in 2005 in order to regulate the banks in Turkey. The Law consisted of fifteen parts and 169 articles; article 24 refers to the audit committee, the qualifications of the members, the responsibilities and duties were defined. According to the article 24: "Banks' board of directors shall establish an audit committee(s) for the execution of the audit and monitoring functions of the board of directors. An audit committee shall consist of minimum two members. Audit committee members shall be appointed amongst the members of the board of directors who do not have executive duties. For banks operating in Turkey as branches, a member of the board of managers to whom no executive unit is attached shall be appointed to fulfil the duties of audit committee.

Members of the audit committee shall bear the qualifications to be set by the Board. The information and documents attesting to such qualifications shall be submitted to the Agency within seven working days, at the latest, following the date of appointment.

The audit committee shall, one every six months at the maximum, report to the board of directors the results of its activities; the measures to be taken in the bank; the practices that need to be introduced; as well as other matters that it deems necessary for the sound operation of the bank." (The Banks Association of Turkey, 2008)

\section{Literature Review}

The studies made in literature have generally focused on the structure and effectiveness of the AC.

Noland et al. (2004) analyzed the value that audit committees added to small commercial banks. The authors were able to evaluate specific internal control questions that assessed the benefit of having an audit committee. The findings of this study, for the most part, are aligned with the findings of the 1999 Committee of Sponsoring Organizations study. This study finds that institutions with audit committees report more internal controls in place on most questions than institutions without audit committees. The most important finding of this study is that institutions with audit committee members who had banking or financial experience reported significantly more effective internal controls than institutions without this expertise on their audit committee.

Buckby et al. (1996) investigated the association between the composition of the AC and ACE by using survey responses from the $\mathrm{AC}$ chairperson, non-executive director and internal audit manager of a sample of Australian listed companies. The results of this study indicated that $\mathrm{AC}$ independence, expertise and financial literacy were all important determinants of ACs.

Empirical studies provide mixed evidence on the impact of AC size on earnings management. Karamanou and Vafeas (2005) researched the relation between corporate board, the characteristics of the AC and the accuracy of management earnings forecasts. They have found that board independence and committee expertise are positively related, whereas board and AC sizes are negatively related to the market reaction to a forecast. Lin et al. (2006) find that $\mathrm{AC}$ size is negatively related to earnings management, implying that a certain minimum number of AC members may be relevant to the quality of financial reporting. On the other hand Xie et al. (2003) and Bédard et al. (2004) find no significant association between $\mathrm{AC}$ size, measured by the number of directors on the committee, and earnings management. Abbott et al. (2004) find no association between AC size and earnings restatement.

Beasley et al. (2000) investigated whether the number of AC meetings has an impact on the possibility of having fraud financial reports in the health-care and the technology businesses. The results of their study indicate that there was a negative relationship between the number of meetings and the likelihood of fraud.

Members' diligence is also very important in performing AC's responsibilities effectively and with integrity (Sharma, 2004). Since diligence is extremely subjective to observe directly, most researchers use AC meeting frequency as a proxy of diligence (Raghunandan and Rama, 2003). Kalbers and Fogarty (1993) surveyed chief financial officers, chief internal auditors and external audit partners to examine their perceptions of AC diligence. They defined diligence as the level of preparation, care, independence and level of activity of the AC chair and other members. They found a significant positive relationship between diligence and perceived ACE.

Bliss et al. (2007) argued the relationship between a firm's corporate governance characteristics and audit fees also whether having more independent directors on AC moderates the auditor's perceived inherent risk when CEO duality is present. Study indicated that the presence of CEO duality on the board, a proxy for board independence is 
associated with higher audit fees and that positive relation is significantly weakened when the firm has a higher proportion of independent directors on AC.

Krishnan and Lee (2009) documented a strong negative association between litigation risk and AC members with accounting financial expertise. Song and Windram (2000) resulted that in UK companies having AC members with high level of financial experience have less possibility to face financial reporting problems. McMullen and Raghunandan (1996) found that companies with financial reporting problems were less likely to have members who have a Certified Public Accountant (CPA) on their ACs.

Bédard et al. (2004) examined that financial expertise of the AC has negative impact on aggressive earnings management. Krishnanand and Visvanathan (2009) discussed the relationship between audit fees and the financial expertise of $\mathrm{AC}$ which was indicated by them as the key aspect of the ACE. They used the data from Standard \& Poor's (S\&P) 500 firms all audited by Big 5 auditors between the years 2000 and 2002 and estimated audit fee model. They found that after controlling for several board and audit company characteristics and firm characteristics, audit pricing is negatively related to accounting financial expertise.

McDaniel et al. (2002) conducted an experiment using audit firm managers and executive MBA graduates to examine the influence of expertise on the assessment of financial reporting quality. They found that experts made better assessment of financial reporting quality compared to non-experts. They concluded that efforts to enhance AC financial expertise might influence ACs' assessments of financial reporting quality.

Many studies argue that AC members' expertise or experience is directly associated with effective functioning of AC (Bedard et al., 2004; Beasley and Salterio, 2001 and DeZoort and Salterio, 2001). Since the AC's main task is to oversee corporate financial reporting and auditing processes, its members should possess sufficient expertise to understand the issues to be investigated or discussed by ACs (Lin et al., 2008).

Lee and Stone (1997) studied 100 US multinational companies and described a mismatch between ACs' stated responsibilities and the levels of instrumental experience (defined as skills related to accounting, auditing and control issues) among members. DeFond et al. (2005) investigated association between the market reaction to the appointment of directors with financial expertise to the $\mathrm{AC}$ and they found a positive association between them.

In addition, DeZoort and Salterio (2001) conducted an experiment to examine the association between AC expertise and the ability of such committees to resolve auditor and management disputes. They found that AC expertise was positively associated with $\mathrm{AC}$ member support for an auditor in substance disputes.

\section{Research Design \& Methodology}

\subsection{Sample Selection}

In this study totally 20 banks samples were chosen, 10 banks for each of Turkey and UK. Turkey has a population of commercial banks of 32 banks comprising 3 state- owned banks, 11 privately-owned banks, 1 bank under deposit insurance fund, 11 foreign banks founded in Turkey and 6 foreign banks having branches in Turkey. The study excluded the bank under deposit insurance fund and foreign banks having branches in Turkey and it was chosen 10 samples within rest of the banks. For UK samples, it was chosen $10 \mathrm{UK}$ banks that classified on the official site of the Financial Service Authority and incorporated in the UK.

Table 1. List of Turkish and UK sample banks

\begin{tabular}{cll}
\hline & Turkish Sample Banks & UK Sample Banks \\
\hline 1 & Türkiye Cumhuriyeti Ziraat Bankası A.Ş. & Barclays Bank plc \\
\hline 2 & Türkiye Halk Bankası A.Ş. & Lloyds TSB Bank plc \\
\hline 3 & Türkiye Vakıflar Bankası T.A.O. & Hsbc plc \\
\hline 4 & Alternatif Bank A.Ş. & Standard Chartered Bank \\
\hline 5 & Anadolubank A.Ş. & The Royal Bank of Scotland plc \\
\hline 6 & Türkiye Garanti Bankası A.Ş. & Ulster Bank Ltd \\
\hline 7 & Türkiye İş Bankası A.Ş. & Clydesdale Bank plc \\
\hline 8 & Yapı ve Kredi Bankası A.Ş. & Co-Operative Bank plc. \\
\hline 9 & Denizbank A.Ş. & Investec Bank plc \\
\hline 10 & Finans Bank A.Ş. & Bank of Scotland plc \\
\hline
\end{tabular}




\subsection{Data, Method and Hypothesis Development}

This section defines the variables which will be used to analyze the relationship between AC characteristics and bank performance measures. This section will also provide information about regression method and build up the hypothesis and will interpret the regression analysis in the light of regression results.

\subsubsection{Data Variables}

Data are obtained from sample of Turkish and UK banks' annual reports as well as information from the Banks Association of Turkey, Datamonitor and the FAME databases for the period 2006 - 2010.

The subject-matter variables to analysis appear in Table-2: As dependent variable 3 variables; and as independent variable 8 variables are used.

Table 2. Variable definition

\begin{tabular}{l} 
Independent Variables \\
\hline $\begin{array}{l}\text { Number of } \\
\text { Audit }\end{array}$ Combers in \\
(ACMMBR)
\end{tabular}

Audit Committee Meetings (ACMEET)

Financial Expertise of Audit

Committee Members

(FINEXP) experience.

A grouped variable "1" if the numbers of AC meetings are between 2-6; "2" if they are between 7-11 and, "3" if they are 12 and more. [This variable had been transformed into dummy variable (three variables, yet only two of them are used in analyzing) in order to process the regression at STATA].

Percentage of AC member who had at least 10 years of accounting or finance A grouped variable "1" if all members had bachelor's degree; "2" if at least one

Education Level of Audit member had master's degree (except doctoral degree); "3" if at least one member Committee Members had doctoral degree. [This variable had been transformed into dummy variable (EDULEV) (four dummy variables, yet only three of them are used in analyzing) in order to process the regression at STATA]. A grouped variable "1" if average age of members in AC is between "35 -40"; "2"

Age of Audit Committee Members (AGEMMBR) if it is between "41-46"; "3" if it is between "47-52" and, "4" if it is above 52. (This variable had been transformed into dummy variable (three variables, yet only two of them are used in analyzing) in order to process the regression at STATA).

A grouped variable "1" if average experience years of members in AC are between

Experience of Audit "10-15"; "2" if they are between "16-21"; "3" if they are between "22-27" and, "4"

Committee Members if it is above 27. [This variable had been transformed into dummy variable (four (EXPMMBR) dummy variables, yet only three of them are used in analyzing) in order to process the regression at STATA].

\begin{tabular}{lll}
\hline $\begin{array}{l}\text { Gender } \\
\text { (GENDMMBR) }\end{array}$ & Diversity & Proportion of woman members in the AC. \\
\hline
\end{tabular}

Dependent Variables

Return on Asset (ROA) A ratio variable as return on assets of sample banks.

Return on Equity (ROE) A ratio variable as return on equities of sample banks.

Net Interest Margin (NIM) $\quad$ A ratio variable as net interest margins of sample banks.

\subsubsection{Model and Software Program}

In this study, due to the data set have both time series (2006-2010) and a cross-sectional component (dependent and independent variables) Panel data methodology is used and analyses relationships between dependent and independent variables. It was also analysis of variance (ANOVA) used in testing the hypotheses and to measure the differences and similarities between the sample banks according to their different characteristics (Tarawneh, 2006). 
The data collected were prepared to make them ready for statistical and econometric processing. The data analyses involved the use of descriptive statistics. Excel software has been used to enter and code the data that have been collected from a variety of sources. Then these data were exported from Excel to the STATA (statistics and data) software program to produce the descriptive statistics. The STATA is a software system for data analysis.

In order to understand the connection between the AC characteristics and bank performance indicators we have developed those three hypotheses:

H1: Characteristics of Audit committee effectiveness is associated with return on asset.

H2: Characteristics of Audit committee effectiveness is associated with return on equity.

H3: Characteristics of Audit committee effectiveness is associated with net interest margin.

There are 3 major limitations in this study. First, this study did not reflect the whole banking industry in UK and Turkey as the sample sizes selected are relatively small, which included only 10 sample banks for each country and just focused on commercial banks. Thus, the population may not be reflected by the sample banks. In this case, the results should not be generalized.

Second, this study uses a deductive research approach and quantitative research strategy relying on secondary data. The annual reports of banks, both in hard copy and on-line versions as well as information from the Datamonitor and the FAME databases were used extensively.

Third, some of the banks data used in this investigation have been manually collected. Although the researcher took all necessary care to be accurate, he is, however, susceptible to human error in the process.

The descriptive statistics of dependent and independent variables of Turkish and UK sample banks are elicited in the Table 3 respectively. Considering those descriptive statistics together will help to make a comparison between two countries.

Table 3. Descriptive statistics of the dependent and independent variables

\begin{tabular}{llllllllllll}
\hline \multicolumn{1}{c}{ Turkish Sample Banks } & & \multicolumn{7}{c}{ UK Sample Banks } \\
\hline Variable & Obs & Mean & $\begin{array}{l}\text { Std. } \\
\text { Dev. }\end{array}$ & Min & Max & Variable & Obs & Mean & $\begin{array}{l}\text { Std. } \\
\text { Dev. }\end{array}$ & Min & Max \\
\hline ACINDEP & 50 & 0,44 & .7329 & 0 & 2 & ACINDEP & 50 & 4,46 & .9733 & 3 & 6 \\
\hline ACMMBR & 50 & 2,28 & .4535 & 2 & 3 & ACMMBR & 50 & 4,46 & .9733 & 3 & 6 \\
\hline ACMEET & 50 & 1,92 & .9655 & 1 & 3 & ACMEET & 50 & 1,4 & .4948 & 1 & 2 \\
\hline FINEXP & 50 & 1 & 0 & 1 & 1 & FINEXP & 50 & 1 & 0 & 1 & 1 \\
\hline EDULEV & 50 & 2,22 & .8154 & 1 & 3 & EDULEV & 50 & 1,4 & .6700 & 1 & 3 \\
\hline AGEMMBR & 50 & 3,54 & .7060 & 2 & 4 & AGEMMBR & 50 & 4 & 0 & 4 & 4 \\
\hline EXPMMBR & 50 & 3,5 & .7626 & 2 & 4 & EXPMMBR & 50 & 4 & 0 & 4 & 4 \\
\hline GENDMMBR & 50 & 0,05 & .1558 & 0 & 0,5 & GENDMMBR & 50 & .0474 & .0858 & 0 & .25 \\
\hline EDULEV1 & 50 & 0,24 & .4314 & 0 & 1 & EDULEV1 & 50 & .7 & .4629 & 0 & 1 \\
\hline EDULEV2 & 50 & 0,3 & .4629 & 0 & 1 & EDULEV2 & 50 & .2 & .4040 & 0 & 1 \\
\hline EDULEV3 & 50 & 0,46 & .5035 & 0 & 1 & EDULEV3 & 50 & .1 & .3030 & 0 & 1 \\
\hline EXPMMBR2 & 50 & 0,16 & .3703 & 0 & 1 & EXPMMBR1 & 50 & 1 & 0 & 1 & 1 \\
\hline EXPMMBR3 & 50 & 0,18 & .3881 & 0 & 1 & EXPMMBR1 & 50 & 1 & 0 & 1 & 1 \\
\hline EXPMMBR4 & 50 & 0,78 & .8154 & 0 & 1 & ACMEET1 & 50 & .6 & .4948 & 0 & 1 \\
\hline ACMEET1 & 50 & 0,5 & .5051 & 0 & 1 & ACMEET2 & 50 & .4 & .4948 & 0 & 1 \\
\hline ACMEET2 & 50 & 0,08 & .2740 & 0 & 1 & ROA & 50 & .003 & .0121 & .060 & .017 \\
\hline ACMEET3 & 50 & 0,47 & .5045 & 0 & 1 & ROE & 50 & .039 & .259 & -.091 & .353 \\
\hline AGEMMBR2 & 50 & 0,12 & .3283 & 0 & 1 & NIM & 50 & .016 & .013 & .006 & .101 \\
\hline
\end{tabular}




\begin{tabular}{llllll}
\hline AGEMMBR3 & 50 & 0,22 & .4185 & 0 & 1 \\
\hline AGEMMBR4 & 50 & 0,66 & .4785 & 0 & 1 \\
\hline ROA & 50 & 0,022 & .0065 & 0,007 & 0,041 \\
\hline ROE & 50 & 0,199 & .0645 & 0,06 & 0,344 \\
\hline NiM & 50 & 0,041 & .0094 & 0,026 & 0,06
\end{tabular}

\section{Research Results}

We used the linear regression analysis (Collier and Gregory, 1996; Abbott and Parker, 2000; Abbott et al., 2003; Bliss et al., 2007) to understand the linkage between variables because it is more suitable when the dependent variable is measured as a ratio scale. Here we are going to assess the results of regression analysis which try to connect the dependent variables, ROA, ROE and NIM with the AC characteristics which we set as independent variables.

\subsection{Turkish Sample Banks}

\subsubsection{Return on Assets (ROA)}

We did exclude those variables from the model, EDULEV1 (.932), EDULEV2 (.686), EXPMMBR1 (.382), EXPMMBR3 (.355), AGEMMBR3 (.339), ACMEET1 (.307), ACMMBR (.237), ACMEET2 (.189), GENDMMBR (.177), respectively (The numbers in the parenthesis are the significance level pertaining to those variables). Finally, AGEMMBR2 (-.011) and ACINDEP (-.002) remained and the model will be as:

$\mathrm{ROA}=(-.011 \mathrm{AGEMMBR} 2)+(-.002 \mathrm{ACINDEP})$

Accordingly, a unit of decrease in the age of directors (from 41 to over 46 years) in the AC will increase the level of ROA by 0.011 points and a unit of decrease in the numbers of independent directors in the AC increase the level of ROA by 0.002 points.

\subsubsection{Return on Equity (ROE)}

We opted out the variables of the analysis respectively in their values of significance on the Coefficients table, accordingly, ACMEET1 (.795), EDULEV1 (.769), EDULEV2 (.654), ACMMBR (.615), GENDMMBR (.602), ACMEET2 (.303), EXPMMBR3 (.241), EXPMMBR1 (.216). Lastly, those are the remaining variables: AGEMMBR3 (-.125), AGEMMBR2 (-.132) and ACINDEP (-.038) thus the model will be as;

$\mathrm{ROE}=(-.125$ AGEMMBR3 $)+(-.132 \mathrm{AGEMMBR} 2)+(-.038 \mathrm{ACINDEP})$

Accordingly, a unit of decrease in the age of directors (from 47 to over 52 years) in the AC will increase the level of ROE by 0.125 points; a unit a unit of decrease in the age of directors (from 41 to over 46 years) $\mathrm{n}$ the AC will increase the level of ROE by .132 points and a unit of decrease in the numbers of independent directors in the AC increase the level of ROA by 0.038 points.

\subsubsection{Net Interest Margin (NIM)}

We selected the variables of the analysis respectively in their values of significance on the Coefficients table, accordingly, ACMEET2 (.913), EXPMMBR3 (.401), EDULEV1 (.182), ACMEET1 (.166), ACMMBR (.128), GENDMMBR (.112), lastly, those are the remaining variables: AGEMMBR3 (-.015), ACINDEP (-.004), EXPMMBR1 (-.020), AGEMMBR2 (-.022) and EDULEV2 (.012) thus the model will be as;

$\mathrm{NIM}=(-.015 \mathrm{AGEMMBR} 3)+(-.022 \mathrm{AGEMMBR})+(.004 \mathrm{ACINDEP})+(-.020 \mathrm{EXPMMBR} 1)+.012 \mathrm{EDULEV} 2$

Accordingly, a unit of decrease in the age of directors (from 47 to over 52 years) in the AC will increase the level of NIM by 0.015 points; a unit of decrease in the age of directors (from 41 to over 46 years) in the AC will increase the level of NIM by 0.022 points and a unit of decrease in the numbers of independent directors in the AC increase the level of NIM by 0.004 points; a unit of decrease in the experience years of directors (from 10 to over 15 years) in the $\mathrm{AC}$ will increase the level of NIM by 0.020 points; a unit of increase in the $\mathrm{AC}$ with an at least one member had master's degree will increase the NIM level by 0.012 .

\subsection{UK Sample Banks}

\subsubsection{Return on Assets (ROA)}

We exclude independent variables from Coefficients table with more than .05 significance level starting with the greatest number in order to provide significance to the model. Thus, we did exclude those variables from the model, 
GENDMMBR (.740), EDULEV2 (.705), EDULEV1 (.440), ACMMBR (.272) (The numbers in the parenthesis are the significance level pertaining to those variables). Finally, ACMEET1 (-.008) remained and the model will be as:

$\mathrm{ROA}=-.008 \mathrm{ACMEET} 1$

Accordingly, a unit of decrease in the meetings of directors (from 2 to 6 meetings) in the AC will increase the level of ROA by 0.008 points.

\subsubsection{Return on Equity (ROE)}

We opted out the variables of the analysis respectively in their values of significance on the Coefficients table, accordingly, EDULEV2 (.999), GENDMMBR (.934), EDULEV1 (.744), ACMMBR (.144). Lastly, ACMEET1 $(-.227)$ remained and the model will be as:

$\mathrm{ROE}=-.227 \mathrm{ACMEET} 1$

Accordingly, a unit of decrease in the meetings of directors (from 2 to 6 meetings) in the AC will increase the level of ROA by 0.227 points.

\subsubsection{Net Interest Margin (NIM)}

We selected the variables of the analysis respectively in their values of significance on the Coefficients table, accordingly, GENDMMBR (0.883), EDULEV2 (.642), ACMMBR (.581), EDULEV1 (.543) and ACMEET1 (.131). The regression result proves that there is no significant relationship between the AC characteristics and NIM though all coefficients are positive yet they are not significant.

Table 4. Model summary of regression (Turkey)

\begin{tabular}{lcccccc}
\hline ROA & Coef. & Std. Err. & $\mathbf{Z}$ & $\mathbf{P}>|\mathbf{z}|$ & {$[\mathbf{9 5 \%}$ Conf. } & Interval] \\
\hline ACINDEP & -.003325 & .0014341 & -2.32 & 0.020 & -.0061358 & -.0005143 \\
\hline AGEMMBR2 & -.0110481 & .0056258 & -1.96 & 0.050 & -.0220744 & -.0000217 \\
\hline ROE & & & & & \\
\hline ACINDEP & -.0388555 & .0133689 & -2.91 & 0.004 & -.0650581 & -.012653 \\
\hline AGEMMBR2 & -.1327023 & .0524446 & -2.53 & 0.011 & -.2354917 & -.0299128 \\
\hline AGEMMBR3 & -.1252847 & .0590276 & -2.12 & 0.034 & -.2409766 & -.0095927 \\
\hline NIM & & & & & & \\
\hline ACINDEP & -.0045409 & .0019724 & -2.30 & 0.021 & -.0084068 & -.000675 \\
\hline EDULEV2 & .0122388 & .0039371 & 3,11 & 0.002 & .0045223 & .0199553 \\
\hline AGEMMBR2 & -.0229765 & .0077376 & -2.97 & 0.003 & -.038142 & -.0078111 \\
\hline EXPMMBR1 & -.020313 & .0079486 & -2.56 & 0.011 & -.0358919 & -.0047341 \\
\hline
\end{tabular}

Table 5. ANOVA of regression (Turkey)

\begin{tabular}{lccccc}
\hline ROA-ANOVA & Partial SS & Df & MS & F & Prob > F \\
\hline Regression & .000722276 & 11 & .000065661 & 1,85 & 0.0784 \\
\hline Residual & .00134608 & 3 & .000035423 & & \\
\hline Total & .002068357 & 4 & .000042211 & & \\
\hline ROE-ANOVA & Partial SS & Df & MS & F & Prob $>$ F \\
\hline Regression & .091641358 & 11 & .008331033 & 2,82 & 0.0086 \\
\hline Residual & .112158626 & 38 & .002951543 & & \\
\hline Total & .203799984 & 49 & .004159183 & & \\
\hline NIM-ANOVA & Partial SS & Df & MS & F & Prob > F \\
\hline Regression & .001752885 & 11 & .000159353 & 1,24 & 0.0258 \\
\hline Residual & .002587914 & 38 & .000068103 & & .002587914 \\
\hline Total & .004340799 & 49 & .000088588 & & .004340799 \\
\hline
\end{tabular}


Table 6. Model summary of regression (UK)

\begin{tabular}{lcccccc}
\hline ROA & Coef. & Std. Err. & $\mathbf{z}$ & $\mathbf{P}>|\mathbf{z}|$ & {$[\mathbf{9 5 \%}$ Conf. } & Interval] \\
\hline ACMEET1 & -.0081729 & .0037634 & -2.17 & 0.030 & -.015549 & -.0007967 \\
\hline ROE & & & & & & \\
\hline ACMEET1 & -.2272217 & .0689008 & -3.30 & 0.001 & -.3622647 & -.0921786 \\
\hline
\end{tabular}

Table 7. ANOVA of regression (UK)

\begin{tabular}{llcccc}
\hline ROA-ANOVA & Partial SS & df & MS & F & Prob $>$ F \\
\hline Regression & .000966937 & 6 & .000161156 & 1,1 & 0.3804 \\
\hline Residual & .006324126 & 43 & .000147073 & & \\
\hline Total & .007291062 & 49 & .000148797 & & \\
\hline ROE-ANOVA & Partial SS & df & MS & F & Prob $>$ F \\
\hline Regression & .576993099 & 6 & .096165516 & 1,53 & 0.1914 \\
\hline Residual & 270.222 .728 & 43 & .062842495 & & \\
\hline Total & 327.922 .038 & 49 & .066922865 & & \\
\hline
\end{tabular}

\section{Conclusion}

In this dissertation we aimed to associate characteristics of ACE with bank performance in the means of bank measure ratios. We have found relations between some characteristics of ACE and bank performance indicators, even though they are not strongly associated or their contribution may be limited. The results revealed that for Turkish banks, both ROA and ROE had negative association with age of member and independent member of directors. NIM had negative association with independent member of directors and experience years of member in the AC while it had positive association with education level of members (at least one member had master's degree). As for UK banks, number of meetings (from 2 to 6 meetings in a year) in the AC had negative association with ROA and ROE. NIM though all coefficients are positive yet they are not significant. NIM regression for Turkish sample result indicates relationship between audit characteristics and NIM. This paradoxical result may stem from the colinearity problem, as all these variables are heavily correlated with each other. Hence, all the variables are combined into the regression to capture the effect on value.

The difference between two countries mainly stems from independent members in AC. The UK Combined Code recommends that the board should establish an $\mathrm{AC}$ of at least three, or in the case of smaller companies two, independent non-executive directors. In sample of UK banks, all of the members in AC are coming from independent non-executive members. However, in Turkey, it is noted that AC members shall be appointed amongst the members of the board of directors who do not have executive duties (Banking Law No 5411, 2005). And it is not clear that those members should be independent non-executive or not. And it gives a chance to Turkish banks not to use independent non-executive directors. Because of that reason audit independence percentage of UK sample banks is 100 percent while percentage of Turkish sample banks is fairly low (19 percent).

This study resulted that number of independent member of AC has negative associations with ROA, ROE and NIM. It means number of independent member has negative impact on bank financial performances as a means of ROA, ROE and NIM. Bedard et al. (2004) found that aggressive earnings management is negatively associated with the presence of an independent AC. Results found in this study are harmonious with the result of Bedard et al. finding. This also could be an indication that Turkish banking sector for the period of 2006-2010 chose an aggressive earning management strategy due to not to have a lot of independent audit committee members in AC.

We also found that bank performance ratio statistics figures (ROA, ROE and NIM) of UK sample banks significantly are lower than those of Turkish sample banks. This result may indicate that UK sample banks felt the recent financial crises deeper than Turkish sample banks.

The number of meetings (from 2 to 6 meetings in a year) in the AC had negative association with ROA and ROE in UK sample banks. We also found that average number of the meetings in UK sample banks is close to 2 to 6 
meetings annually. However for Turkey sample banks average numbers close to 7 to 12 meetings scale. Negative association for UK sample banks could be an indication that more AC meetings are needed annually for ACE.

\section{References}

Abbott, L. J., Park, Y., \& Parker, S. (2000). The effects of audit committee activity and independence on corporate fraud. Managerial Finance, 26(11), 55-68. http://dx.doi.org/10.1108/03074350010766990

Abbott, L. J., Parker, S., \& Peter, G. F. (2004). Audit committee characteristics and restatements. Auditing: A Journal of Practice and Theory, 23(1), 69-87. http://dx.doi.org/10.2308/aud.2004.23.1.69

Abbott, L. J., Parker, S., Peter, G. F., \& Rama, D. V. (2007). Corporate governance, audit Quality, and the Sarbanes-Oxley Act: Evidence from internal audit outsourcing. The Accounting Review, 82(4), 803-835.

Banking Law No. 5411, pp.18-19.

Beasley, M. S., \& Salterio, S. (2001). The relationship between board characteristics and voluntary improvements in the capability of audit committees to monitor. Contemporary Accounting Research, 18(4), 539-570.

Beasley, M. S., Carcello, J. V., \& Hermanson, D. R. (2000). Should you offer a job to your external auditor?. Journal of Corporate Accounting \& Finance, 11(4), 35-42.

Bedard, J., Chtourou, S. M., \& Courteau, L. (2004). The effect of audit committee expertise, independence, and activity on aggressive earnings management. Auditing: A Journal of Practice \& Theory, 23(2), 13-35.

Bliss, M. A., Muniandy, B., \& Majid, A. (2007). CEO duality, audit committee effectiveness and audit risks a study of the Malaysian market. Managerial Auditing Journal, 22(7), 716-728. http://dx.doi.org/10.1108/02686900710772609

Bromark, R., \& Hoffman, R. (1992). An audit committee for dynamic times. Directors \& Boards, 16(3), 51-60.

Buckby, S., Dunstan, K., \& Savage, R. (1996). A study of the determinants of Australian audit committee effectiveness. Working Paper, Retrieved from http://papers.ssrn.com/sol3/papers.cfm?abstract_id=30561

Campbell, N. (1990). Holding audit committees accountable. Canadian Business Law Journal, 16(2), 134-159.

Chan, K. C., \& Li, J. (2008). Audit committee and firm value: evidence of outside top executives as expert-independent directors. Corporate Governance: An International Review, 16(1), 16-31.

Collier, P. (1993). Audit committees in major UK companies. Managerial Auditing Journal, 8(3), 25-31. http://dx.doi.org/10.1108/02686909310036241

Collier, P., \& Gregory, A. (1996). Audit committee effectiveness and the audit fee. The European Accounting Review, 5(2), 177-198. http://dx.doi.org/10.1080/09638189600000012

DeFond, M. L., Hann, R. N., \& Hu, X. (2005). Does the market value financial expertise on audit committees of boards of directors?. Accounting Research, 43(2), 5-30. http://dx.doi.org/10.2139/ssrn.498822

DeZoort, F. T. (1998). An analysis of experience effects on audit committee members' oversight judgements. Accounting, Organization and Society, 23(1), 1-21. Retrieved from http://www.sciencedirect.com/science/article/pii/S0361-3682(97)00029-9

Financial Reporting Couincil. (2012). The UK corporate governance code and associated guidance. Retrieved from http://www.frc.org.uk/documents/pagemanager/CorporateGovernance/UK\%20Corp\%20Gov\%20Code\%20June $\% 202010 . p d f$

Kalbers, L. P., \& Fogarty, T. J. (1993). Audit committee effectiveness: An empirical investigation of the contribution of power. Auditing: A Journal of Practice \& Theory, 12(1), 24-49.

Karamanou, I., \& Vafeas, N. (2005). The association between corporate boards, audit committees, and management earnings forecasts: An empirical analysis. Journal of Accounting Research, 43(3), 453-486. http://dx.doi.org/10.1111/j.1475-679X.2005.00177.x

Krishnan, G., \& Visvanathan, K. (2009). Do auditors price audit committee's expertise? The case of accounting versus non-accounting financial experts. Journal of Accounting, Auditing \& Finance, 24(1), 115-144. http://dx.doi.org/10.2139/ssrn.1003686

Krishnan, J., \& Lee, J. E. (2009). Audit committee financial expertise, litigation risk, and corporate governance. Auditing: A Journal of Practice and Theory, 28(1), 241-261. http://dx.doi.org/10.2308/aud.2009.28.1.241 
Lee, T., \& Stone, M. (1997). Economic agency and audit committee: Responsibilities and membership composition. International Journal of Auditing, 1(2), 97-116.

Lin, J., Li, J., \& Yang, J. (2006). The effect of audit committee performance on earnings quality. Managerial Auditing Journal, 21(9), 921-933. http://dx.doi.org/10.1108/02686900610705019

Lin, Z. J., Xiao, J. Z., \& Tang, Q. (2008). The roles, responsibilities and characteristics of audit committee in China. Accounting, Auditing \& Accountability Journal, 21(5), 721-751. http://dx.doi.org/10.1108/09513570810872987

McDaniel, L., Martin, R. D., Maines, L. A., \& Peecher, M. E. (2002). Evaluating financial reporting quality: The effect of financial expertise vs. financial literacy. The Accounting Review, 77, 139-167.

McMullen, D. A., \& Raghunandan, K. (1996). Enhancing audit committee effectiveness. Journal of Accountancy, 182(2). 79-81.

Noland, T. G., Nichols, D. L., \& Flesher, D. L. (2004). Audit committee effectiveness in the banking industry. Management Accounting Quarterly (spring), 5(3), 1-4.

Raghunandan, K., \& Rama, D. V. (2003). Audit committee composition and shareholder actions: evidence from voting on auditor ratification. Auditing: A Journal of Practice \& Theory, 22(2), 253-263. http://dx.doi.org/10.2308/aud.2003.22.2.253

Rezaee, Z. (2009). Corporate Governance and Ethics. United States: John Wiley \& Sons.

Rickard, P. (1993). Audit committees - the next generation. Australian Accountant, 63(10), 35-38.

Sharma, V. D. (2004). Board of director characteristics, institutional ownership, and fraud: evidence from Australia. Auditing: A Journal of Practice \& Theory, 23(2), 105-117.

Song, J., \& Windram, B. (2000). Benchmarking audit committee effectiveness in financial reporting. International Journal of Auditing, 8(3), 195-205.

Tarawneh, M. (2006). A comparison of financial performance in the banking sector: some evidence from Omani commercial banks. International Research Journal of Finance and Economics, 3, 101-112.

Vicknair, D., Hickman, K., \& Carnes, K. C. (1993). A note on audit committee independence: evidence from the NYSE on "Grey" area directors. Accounting Horizons, 7(1), 53-57.

Xie, B., Davidson III, W. N., \& DaDalt, P. J. (2001). Earning management and corporate governance: the role of the board and the audit committee. Journal of Corporate Finance, 9(3), 295-316. http://dx.doi.org/10.2139/ssrn.304195 